\title{
On ATPases
}

\author{
Shigeki Minakami \\ Department of Physiological Chemistry and Nutrition, Faculty of \\ Medicine, the University of Tokyo, Tokyo
}

1. Significances of various ATPases in physiological functions of cells were discussed.

2. The properties of $\mathrm{Na}, \mathrm{K}$-activated ATPase from microsomal fraction of guinea pig intestinal mucosa ${ }^{1>2)}$ were discussed in connection with the active cation transport in the slices of the intestinal mucosa.

3. Feed-back control of energy yielding reaction in brain ${ }^{3)}$, intestinal mucosa ${ }^{1)}$ and erythrocytes ${ }^{4)}$ by active cation transport was demonstrated and the mechanism of the control was discussed.

\section{References}

1) S. Kume, S. Minakami and H. Yoshikawa: "Symposium on Enzyme Chemistry" Tokyo, 1964.

2) S. Minakami, T. Saito, S. Kume and H. Yoshikawa: J. Biochem. 57:221, 1965.

3) S. Minakami, K. Kakinuma and H. Yoshikawa: Biochim. Biophys. Acta 78: 808, 1963.

4) S. Minakami, K. Kakinuma and H. Yoshikawa: Biochim. Biophys. Acta 90: 434, 1964. 